\title{
Helminth fauna of wild rabbit Oryctolagus cuniculus in the Canary Islands, Spain
}

\author{
Á. FERNÁNDEZ-ÁLVAREZ ${ }^{1}$, C. FELIU ${ }^{2}$, J. MIQUEL $^{2}$, J. TORRES $^{2}$, P. FORONDA $^{1 *}$
}

\begin{abstract}
${ }^{1}$ University Institute of Tropical Diseases and Public Health of the Canary Islands, University of La Laguna, La Laguna, Tenerife, Canary Islands, Spain 38203, E-mail: pforonda@ull.es; ${ }^{2}$ Laboratory of Parasitology, Faculty of Pharmacy, University of Barcelona, Barcelona, Spain 08028, IRBIO - Institut de Recerca de la Biodiversitat, University of Barcelona
\end{abstract}

\begin{abstract}
Summary
Helminths were examined in 292 wild rabbits (Oryctolagus cuniculus) collected in Tenerife, Fuerteventura, La Palma and El Hierro islands, and La Graciosa islet (Canary Islands, Spain), from 2008 to 2012. Three species of cestodes, Taenia pisiformis (Taeniidae), Andrya cuniculi and Neoctenotaenia ctenoides (Anoplocephalidae), and three species of nematodes Trichostrongylus retortaeformis (Trichostrongylidae), Passalurus ambiguus (Oxyuridae) and Calodium hepaticum (Capillariidae), were identified. Only 2 species ( $N$. ctenoides and $P$. ambiguus) were regularly present in all the islands, with an average prevalence above $50 \%$. Possible causes of the present distribution of helminths are commented. Insular and founder effects on parasite species in isolated ecosystems are demonstrated. The finding of the zoonotic species $C$. hepaticum solely in La Palma, represents a novel identification of this nematode in O. cuniculus in the Canary Islands.
\end{abstract}

Keywords: Oryctolagus cuniculus; Canary Islands; helminth; Calodium hepaticum

\section{Introduction}

In the 15th century, the Canary Islands were conquered by the Spanish Empire and some species of small mammals, including the wild rabbit (Oryctolagus cuniculus) (Lagomorpha: Leporidae), were introduced (Foronda et al., 2003a). This species has colonized successfully most of the habitats of the main islands, achieving a stable population of individuals. Populations were also present in La Graciosa, Alegranza and the Lobos islets, but not in Montaña Clara, where it has been eradicated (Nogales et al., 2006). This is a very important species for hunting and cuniculture sectors, with a strong tradition in the Archipelago (Foronda et al., 2005). However, it has negative ecological effect on islands, as they affect numerous endemic plants and their associated fauna (Nogales et al., 2006; Delibes-
Mateos et al., 2009).

The density of rabbits depends on several factors, i.e. seasonal changes (Cabrera-Rodríguez, 2008) or epidemics such as rabbit hemorrhagic disease (RHD) and myxomatosis (Foronda et al., 2000, 2005). However, it has been demonstrated that rabbit populations are able of recover slower or quicker after a catastrophe (Villafuerte et al., 1995).

At present, two subspecies genetically differentiated are well known (Hardy et al., 1995) and separated geographically. While Oryctolagus cuniculus algirus is restricted to the southwestern of the Iberian Peninsula, North Africa, Mediterranean and Portuguese Atlantic islands, Oryctolagus cuniculus cuniculus is present in the rest of mainland Spain and Europe, and in those places where they have been introduced by humans (Blasco et al., 1996; Branco et al., 2000). In the case of the Canary Islands, the introduced fauna exhibit marked European influences mostly from the Iberian Peninsula, where O. cuniculus is native (Juan et al., 2000). Similarly, species of coccidia and helminths that parasitize this animal have found optimal conditions for their establishment in the Archipelago (Foronda et al., 2000).

The only available data on the occurrence of helminths in wild rabbits in the Canary Islands have been reported on Tenerife island (Foronda et al., 2000, 2003a, 2003b, 2005) and Alegranza islet (Foronda et al., 2003b). So far, the species identified in Tenerife have been three cestodes: Taenia pisiformis (Bloch, 1780) larvae (Taeniidae), Andrya cuniculi (Blanchard, 1891) and Neoctenotaenia ctenoides (Railliet, 1890) (Anoplocephalidae); and two nematodes: Trichostrongylus retortaeformis (Zeder, 1800) (Trichostrongylidae) and Passalurus ambiguus (Rudolphi, 1819) (Oxyuridae); while in Alegranza only N. ctenoides and $P$. ambiguus have been found.

Therefore, the aim of the present study was to widen the existing helminthological data of the wild rabbit population 
in the Canary Islands, describing the helminth parasite fauna present in Fuerteventura, El Hierro and La Palma islands, and La Graciosa islet, where no previous data were available, and extending the previous information for Tenerife.

\section{Materials and methods}

\section{Study area}

The Canary Archipelago presents volcanic origin and is located about $100 \mathrm{~km}$ from the NW coast of Africa, between $13^{\circ} 23^{\prime}$ and $18^{\circ} 8^{\prime} \mathrm{W}$ and $27^{\circ} 37^{\prime}$ and $29^{\circ} 24^{\prime} \mathrm{N}$, in the Macaronesian region. It is comprised of seven main islands and several islets (Fig. 1).

The western (La Gomera, La Palma and El Hierro) and middle (Gran Canaria and Tenerife) islands have mountain ranges of remarkable altitude, which enable the formation of the sea of clouds on the windward slopes, (approximately $1000 \mathrm{~m}$ a.s.1.), by the accumulation of the upper hot dry air and by the lower humid trade winds. Different from the rough middle and western islands, eastern islands (Fuerteventura and Lanzarote) and islets display lower altitudes low rainfall, and are influenced by dry winds blowing from the close Sahara Desert (Juan et al., 2000).

According to altitude and orientation, a variety of habitats or bioclimatic areas displaying differential also marked by vegetation features can be found. In the eastern islands and low zones of the central and western islands, vegetation is characterized by dry xerophytic shrub, while in the rest of the areas in the western and central islands, the habitats - ranging from low to high altitudes- are mixed wood, humid evergreen cloud forest (laurel forest), pine forest and shrub layer dominated by leguminous genera (Nogales et al., 2006). Mean temperature and annual precipitation range from about $21^{\circ} \mathrm{C}$ and $100-300 \mathrm{~mm}$ in coastal zones, and about $9{ }^{\circ} \mathrm{C}$ and $500-800 \mathrm{~mm}$ at higher altitudes, respectively (Table 1).

\section{Host and parasite sampling}

Between 2008 and 2012, a total of 292 wild rabbit were collected from La Palma $\left(708 \mathrm{~km}^{2}\right)$, El Hierro $\left(278 \mathrm{Km}^{2}\right)$, Tenerife $\left(2036 \mathrm{~km}^{2}\right)$, Fuerteventura $\left(1659 \mathrm{~km}^{2}\right)$ and La Graciosa $\left(29 \mathrm{~km}^{2}\right)$ (Table 2), thanks to the contributions of hunters, and with the permission of Excmo. Cabildo Insular of all the islands studied.

Information on capture date, location and age, were recorded. Rabbits were dissected so as to examine both helminth species and burdens. The abdominal cavity was opened and the contents removed. The liver, mesenteries, pelvic area and body cavity were examined. The stomach contents were examined dry (without saline solution) in a large glass Petri dish. The small and large intestines were initially examined directly in sections and their contents filtered through a 100 mesh $(125 \mathrm{~mm})$ sieve.

The total number of cestodes and nematodes were counted for each rabbit, and stored in $70 \%$ ethanol before microscopic study. For species determination under light microscope, cestodes were stained with Semichon's acid carmine, sequentially dehydrated in ethanol, cleared in xylene and mounted in Canada balsam. Nematodes were cleared

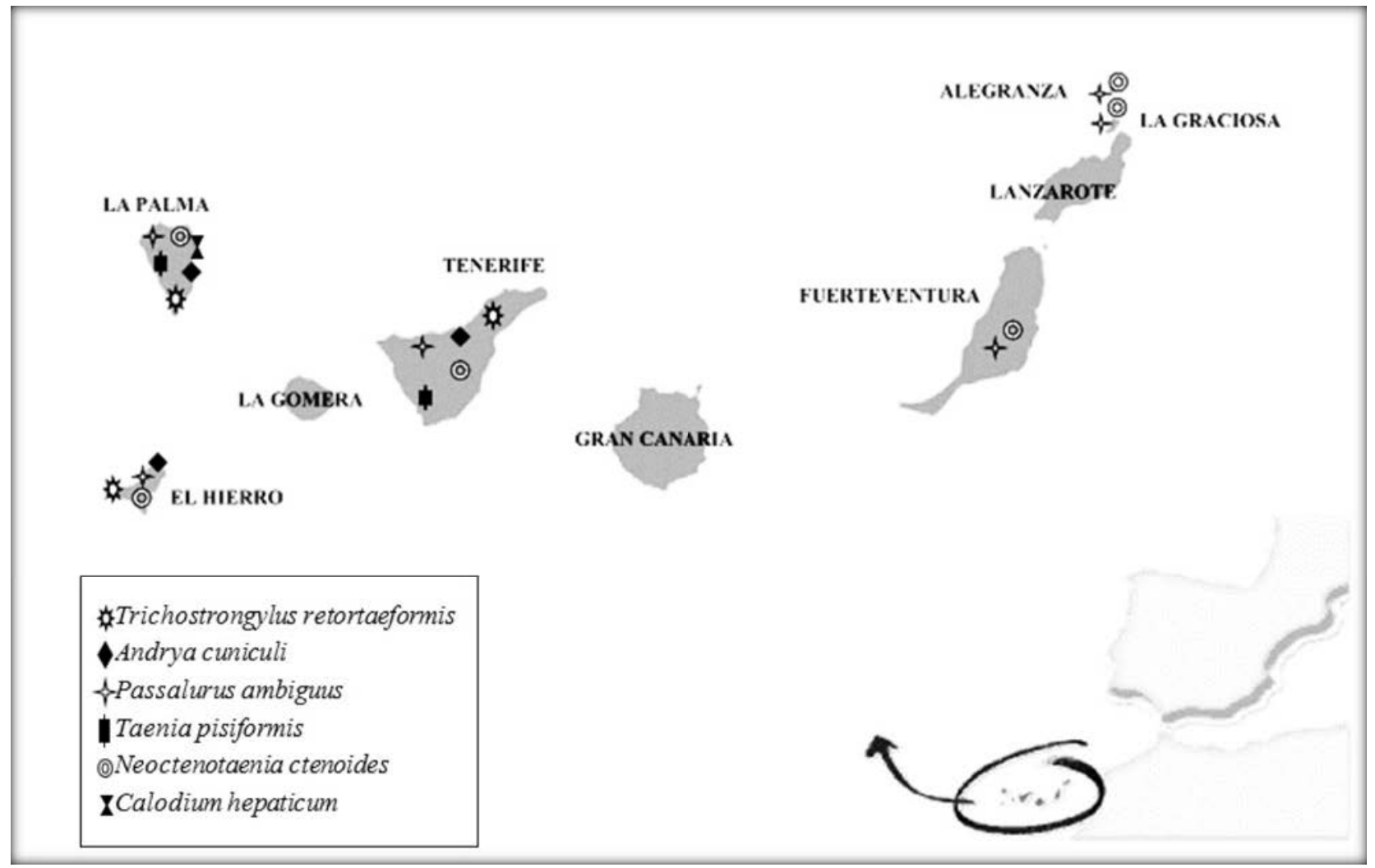

Fig. 1. Distribution of the helminth species detected in the Canary Islands. Data for Alegranza obtained from Foronda et al. (2003b) 
Table 1. Range of values on altitude and climate in the different islands of the Canary Islands (data obtained from $A E M E T$, State Meteorological Agency of Spain)

\begin{tabular}{lcccc}
\hline Island & Altitude $(\mathrm{m})$ & Relative humidity $(\%)$ & Annual rainfall $(\mathrm{mm})$ & Temperature $\left({ }^{\circ} \mathrm{C}\right)$ \\
\hline La Palma & $0-2426$ & $60-78$ & $150-1050$ & $8-22$ \\
El Hierro & $0-1501$ & $70-82$ & $50-850$ & $12-22$ \\
Tenerife & $0-3718$ & $38-82$ & $50-950$ & $4-22$ \\
Fuerteventura & $0-807$ & $64-74$ & $50-250$ & $18-22$ \\
La Graciosa & $0-266$ & $66-68$ & $50-150$ & $18-20$ \\
\hline
\end{tabular}

in Amann's lactophenol. Helminth identification was performed based on previous works by Skrjabin et al. (1950, 1954, 1970), Verster (1969), Beveridge (1978), Tenora and Murai (1978), Hugot et al. (1983) and Tenora et al. (2002).

\section{Data analysis}

The statistical chi-square and ANOVA tests were used to determine differences of the helminth species in prevalence and mean intensity, respectively (Bush et al., 1997), among the different islands. Helminth counts of $P$. ambiguus and $T$. retortaeformis were $\log$ transformed to normalize the distribution. Significance level was $p=0.05$ in both tests.

\section{Results}

Six helminth species were detected in the rabbits, cestodes A. cuniculi, N. ctenoides and T. pisiformis larvae; and nematodes $P$. ambiguus, $T$. retortaeformis and Calodium hepaticum (Bancroft, 1893) [syn. Capillaria hepatica] (Capillariidae).

The statistical analyses showed that the helminth species were irregularly distributed in the Archipelago (Fig. 1). Only two species, $N$. ctenoides and $P$. ambiguus, were regularly found throughout the Archipelago, with $50 \%$ and $58 \%$ prevalence, respectively. The rest of the parasites were characteristic of several islands. La Palma was the only island harboring all six species. In Tenerife, all the species were present except $C$. hepaticum, whilst in El Hierro, only $C$. hepaticum and $T$. pisiformis were absent. Differently, in both Fuerteventura and La Graciosa only two species $N$. ctenoides and $P$. ambiguus were found. Values of the prevalence, mean intensity and range of individual helminths are given in Table 2.

In general, all species, except $C$. hepaticum and $T$. pisiformis on La Palma, and A. cuniculi on El Hierro and La Palma, displayed overall prevalence higher than $10 \%$.

Considering the cestode species, the highest prevalence

Table 2. Prevalence (P \%), mean intensity (MI) and range (in parentheses) of infection for the helminth species found in Oryctolagus cuniculus in the Canary Islands. (Ac: Andrya cuniculi, Nc: Neoctenotaenia ctenoides, Tp: Taenia pisiformis, Pa: Passalurus ambiguus, Tr: Trichostrongylus retortaeformis, Ch: Calodium hepaticum)

\begin{tabular}{|c|c|c|c|c|c|c|}
\hline & $A c$ & $N c$ & $T p$ & $P a$ & $T r$ & $C h$ \\
\hline Island & $\begin{array}{l}\mathrm{P}(\%) \\
\mathrm{MI} \pm \mathrm{SD} \\
\text { (range) }\end{array}$ & $\begin{array}{l}\mathrm{P}(\%) \\
\mathrm{MI} \pm \mathrm{SD} \\
\text { (range) }\end{array}$ & $\begin{array}{l}\mathrm{P}(\%) \\
\mathrm{MI} \pm \mathrm{SD} \\
\text { (range) }\end{array}$ & $\begin{array}{l}\mathrm{P}(\%) \\
\mathrm{MI} \pm \mathrm{SD} \\
\text { (range) }\end{array}$ & $\begin{array}{l}\mathrm{P}(\%) \\
\mathrm{MI} \pm \mathrm{SD} \\
\text { (range) }\end{array}$ & $\begin{array}{l}\mathrm{P}(\%) \\
\mathrm{MI} \pm \mathrm{SD} \\
\text { (range) }\end{array}$ \\
\hline La Palma & 5 & 56 & 7 & 55 & 18 & 0.9 \\
\hline $\mathrm{n}=106$ & $\begin{array}{l}1.8 \pm 1.1 \\
(1-4)\end{array}$ & $\begin{array}{l}1.8 \pm 1.5 \\
(1-8)\end{array}$ & $\begin{array}{l}3 \pm 1.8 \\
(1-5)\end{array}$ & $\begin{array}{l}492.7 \pm 1251.9 \\
(2-9000)\end{array}$ & $\begin{array}{l}42 \pm 50 \\
(2-200)\end{array}$ & $\begin{array}{l}- \\
(6)\end{array}$ \\
\hline $\begin{array}{l}\text { Tenerife } \\
\mathrm{n}=115\end{array}$ & $\begin{array}{l}20 \\
4.5 \pm 4.1 \\
(1-17)\end{array}$ & $\begin{array}{l}35 \\
1.3 \pm 0.5 \\
(1-2)\end{array}$ & $\begin{array}{l}23 \\
8.7 \pm 18 \\
(1-90)\end{array}$ & $\begin{array}{l}52 \\
819.7 \pm 1154.3 \\
(1-5680)\end{array}$ & $\begin{array}{l}50 \\
93.8 \pm 130.9 \\
(1-500)\end{array}$ & $\begin{array}{l}0 \\
- \\
-\end{array}$ \\
\hline El Hierro & 2 & 78 & 0 & 70 & 28 & 0 \\
\hline $\mathrm{n}=50$ & $\begin{array}{l}3 \pm 0 \\
(3)\end{array}$ & $\begin{array}{l}1.8 \pm 0.6 \\
(1-4)\end{array}$ & - & $\begin{array}{l}461.8 \pm 517.2 \\
(2-2000)\end{array}$ & $\begin{array}{l}51.6 \pm 60.6 \\
(4-236)\end{array}$ & - \\
\hline La Graciosa & 0 & 33 & 0 & 87 & 0 & 0 \\
\hline $\mathrm{n}=15$ & $\begin{array}{l}- \\
-\end{array}$ & $\begin{array}{l}1.2 \pm 0.4 \\
(1-2)\end{array}$ & - & $\begin{array}{l}1176.8 \pm 1764 \\
(1-4820)\end{array}$ & - & - \\
\hline Fuerteventura & 0 & 67 & 0 & 67 & 0 & 0 \\
\hline$n=6$ & - & $\begin{array}{l}1 \pm 0 \\
(1)\end{array}$ & - & $\begin{array}{l}772 \pm 1286.5 \\
(14-3000)\end{array}$ & - & - \\
\hline $\begin{array}{l}\text { General } \\
n=292\end{array}$ & $\begin{array}{l}10 \\
3.9 \pm 3.8 \\
(1-17)\end{array}$ & $\begin{array}{l}50 \\
1.6 \pm 1.1 \\
(1-8)\end{array}$ & $\begin{array}{l}12 \\
8.6 \pm 19.1 \\
(1-90)\end{array}$ & $\begin{array}{l}58 \\
660.7 \pm 1176.6 \\
(1-9000)\end{array}$ & $\begin{array}{l}31 \\
76.5 \pm 112 \\
(1-500)\end{array}$ & $\begin{array}{l}0.34 \\
- \\
(6)\end{array}$ \\
\hline
\end{tabular}


was found for $N$. ctenoides in El Hierro (78 \%), while in the group of the nematodes, $P$. ambiguus showed the highest prevalence, specifically in La Graciosa islet (87\%). Comparative analysis of prevalence of the parasite species demonstrated the existence of significant differences in most of them. Attending to the general prevalence of cestodes and nematodes, tapeworms are significantly higher than nematodes $\left(\chi^{2}=7.8 ; \mathrm{p}<0.05\right)$.

Regarding to the distribution of each helminth species, $A$. cuniculi showed higher prevalence in Tenerife than in La Palma $\left(\chi^{2}=11.6 ; \mathrm{p}<0.05\right)$ and El Hierro $\left(\chi^{2}=9.1 ; \mathrm{p}<\right.$ 0.05 ), and $T$. pisiformis was more prevalent in Tenerife compared to La Palma $\left(\chi^{2}=12.1 ; \mathrm{p}<0.05\right)$. However, $N$. ctenoides was more frequent in Tenerife than in La Palma $\left(\chi^{2}=9.7 ; \mathrm{p}<0.05\right)$ and El Hierro $\left(\chi^{2}=17.0 ; \mathrm{p}<0.05\right)$; and El Hierro compared to La Graciosa $\left(\chi^{2}=10.5\right.$; $\left.p<0.05\right)$ and La Palma $\left(\chi^{2}=7.3 ; \mathrm{p}<0.05\right)$.

With respect to nematodes, $P$. ambiguus was more prevalent in Tenerife than in El Hierro $\left(\chi^{2}=4.5 ; \mathrm{p}<0.05\right)$ and La Graciosa $\left(\chi^{2}=6.4 ; \mathrm{p}<0.05\right)$; and La Palma compared to La Graciosa $\left(\chi^{2}=5.5 ; \mathrm{p}<0.05\right) ;$ T. retortaeformis showed higher values in Tenerife than in La Palma $\left(\chi^{2}=\right.$ 25.7; $<<0.05)$ and El Hierro $\left(\chi^{2}=7.1 ; p<0.05\right)$.

\section{Discussion}

The helminth fauna of $O$. cuniculus in the Canary Islands appears qualitatively impoverished and restricted to six species ( 3 cestodes and 3 nematodes). Majority of these species, except of $T$. retortaeformis and $C$. hepaticum, show a clear specificity regarding to Leporidae species (Blasco, 1996).

The species that are present in all the examined islands, $N$. ctenoides and $P$. ambiguus, complete their life cycles primarily in the rabbit as definitive host and show a co-evolution process and biogeography closely related to this host (Blasco, 1996).

The loss of helminth species in O. cuniculus in the Macaronesian islands has been demonstrated previously in the context of the Palearctic Region (Foronda et al., 2003b). This process can be explained by the general characteristics of the parasitofauna in isolated ecosystems (Mas-Coma \& Feliu, 1984; Magnanou \& Morand, 2006). Similarly, the reduction in the number of parasite species in Fuerteventura, La Graciosa and Alegranza has been noticed (see Foronda et al., 2003b for Alegranza). This could be explained basically by three aspects. First, the bioclimatic differences, especially in temperature and vegetation, between the western (Tenerife, La Palma, La Gomera and El Hierro) and the eastern islands situated closer to Africa (Gran Canaria, Fuerteventura, Lanzarote, La Graciosa and Alegranza, see Table 1). Second, the small size of La Graciosa and Alegranza, means lower surface and more biodiversity loss (Mas-Coma \& Feliu, 1984, Mas-Coma et al., 2000), limiting species with life cycles dependent of the external environment (monoxenous geohelminth nematodes as $T$. retortaeformis, and platyhelminthes, as $\mathrm{A}$. $\mathrm{cu}$ niculi and $T$. pisiformis). These two last species has been found with no homogenous distribution previously (Foronda et al., 2003a). It could be due to an irregular distribution of the intermediate hosts for A. cuniculi, and the adult forms in its definitive hosts for $T$. pisiformis (see Foronda et al., 2003a). Although the life cycle for $\mathrm{A}$. $\mathrm{cu}$ niculi is still unknown, it is likely similar to other Anoplocephalidae species, with oribatid mites as intermediate hosts. On the other hand, the irregular presence of T. pisiformis could be explained by the same distribution found for the adult forms in Canaries, where dogs (Canis familiaris) act as definitive hosts (see Foronda et al., 2003a).

The last, third aspect may concern the relatively low number of hosts examined in the eastern islands.

In relation to these processes, the analyses of rabbits from La Gomera, Gran Canaria and Lanzarote would be of high interest since it could confirm these three hypotheses. The three concerns are almost confirmed with the results obtained in the present work. In this sense, one of the most highlighted result is rather high prevalence of $P$. ambiguus in the small islets ( $87 \%$ ), presumable due to the direct life cycle without free-living larval stages, and because of the limited territory that implies more frequent contact between rabbits (Magnanou \& Morand, 2006); this is in accordance with the fact that in continental regions the prevalence found for $P$. ambiguus is rather lower $(12 \%$ in Lepus europaeus from Slovakia) (Dubinský et al., 2010). Further remarkable observation is the higher prevalence of T. retortaeformis in Tenerife (58\%), comparing with the rest of western islands. This result fits with the larger size of Tenerife and therefore the smaller impact on the prevalence of parasitic species, including those with dependent cycles of environmental factors. The same fact might explain the prevalence of $A$. cuniculi in Tenerife and El Hierro.

Finally, C. hepaticum is a cosmopolitan zoonotic nematode that parasitizes the liver of mammal species, particularly rats and mice, although the list of host species is exceptionally long, including wild lagomorphs (Moreira et al., 2013). Cases of human infections with $C$. hepaticum have been reported in different continents and many of them have proved to be fatal (see Mowat et al., 2009). The focal distribution of $C$. hepaticum was reported in rodents from La Palma, with prevalence of $100 \%$ in Rattus norvegicus, $37.5 \%$ in Rattus rattus and $22.5 \%$ in Mus musculus domesticus but the parasite was rare or absent in the rest of the islands (Sanchez, 2013). This fact could explain the finding of this nematode in wild rabbit only in La Palma but the current result represents a novel identification of this nematode in O. cuniculus in the Canary Islands.

\section{Acknowledgements}

This work was supported by projects "Programa Nacional de Biodiversidad, Ciencias de la Tierra y Cambio Global: Subprograma de Biología de Organismos y Sistemas" (CGL 2006-04937 and CGL2009-07759BOS) of the "Ministerio de Ciencia y Educación".

We thank to "Excmos. Cabildos Insulares" of Tenerife, La 
Palma, El Hierro, Fuerteventura and Lanzarote, and hunters from these islands. We also are grateful to D. LuisRavelo for the manuscript review.

\section{References}

BEVERIDGE, I. (1978): A taxonomic revision of the genera Cittotaenia Riehm, 1881, Ctenotaenia Railliet, 1893, Mosgovoyia Spassky, 1951 and Pseudocittotaenia Tenora, 1976 (Cestoda: Anoplocephalidae). Mémoires du Muséum d'Histoire Naturelle, Paris. Série A, Zoologie, 107: 1 - 64

Blasco, S. (1996): Sobre las helmintofaunas de Erinaceus europaeus Linnaeus, 1758 (Insectivora: Erinaceidae), Arvicola terrestris (Linnaeus, 1758) (Rodentia: Arvicolidae) y Oryctolagus cuniculus (Linnaeus, 1758) (Lagomorpha: Leporidae) en la España peninsular. PhD thesis, Spain, Barcelona: University of Barcelona

Blasco, S., Torres, J., Feliu, C., Casanova, J. C., Miquel, J., Moreno, S. (1996): The helminthfauna of Oryctolagus cuniculus (Linnaeus, 1758) in the Iberian Peninsula. Faunistic and ecological considerations. Parasite, 4: $327-333$

Branco, M., Ferrand, N., Monnerot, M. (2000): Phylogeography of the European rabbit (Oryctolagus cuniculus) in the Iberian Peninsula inferred from RFLP analysis of the cytochrome b gene. Heredity, 4: $307-317$

Bush, A. O., Lafferty, K. D., Lotz, J. M., Shostak, A. W. (1997): Parasitology meets ecology on its own terms: Margolis et al. revisited. J. Parasitol., 83(4): 575 - 583

CABRERA-RodríGuEZ, F. (2008): Seasonal abundance and management implications for wild rabbits (Oryctolagus cuniculus) on La Palma, Canary Islands. Wildl. Biol. Pract., 4(2): 39 - 47. DOI: 10.2461/wbp.2008.4.4

Delibes-Mateos, M., Ferreras, P., Villafuerte, R. (2009): European rabbit population trends and associated factors: a review of the situation in the Iberian Peninsula. Mammal Rev., 39(2): 124 - 140. DOI: 10.1111/j.13652907.2009.00140.x

DUBINSKÝ, P., VASILKOVÁ, Z., HuRníKOVÁ, Z., MiterpákovÁ, M., SlameČKA, J., JurČíK, R. (2010): Parasitic infections of the European brown hare (Lepus europaeus Pallas, 1778) in south -western Slovakia. Helminthologia, 47(4): 219 - 225. DOI: 10.2478/S11687-0100034-7

Moreira, V. L., Giese, E. G., Silva, D. C., Melo, F. T., Furtado, A. P., Maldonado, A. Jr., Santos, J. N. (2013): Calodium hepaticum (Nematoda: Capillariidae) in synanthropic rodents (Rattus norvegicus and Rattus rattus) in Eastern Amazonia. Rev. Bras. Parasitol. Vet., 22(2): 265 - 269. DOI: 10.1590/S1984-29612013000200046

Foronda, P., DEl CASTIllo, A., PiÑERo, J., CASANOVA, J. C. (2000): Helminths and virus infections of wild rabbit in Tenerife (Canary archipel). Acta Parasitolog., 45: 176 Foronda, P., Del Castillo, A., Abreu, N., Figueruelo, E., Piñero, J., Casanova, J. C. (2003a): Parasitic helminths of the wild rabbit, Oryctolagus cuniculus, in different bioclimatic zones in Tenerife, Canary Islands. J. Helminthol., 77(4): 305 - 309. DOI: 10.1079/JOH2003182
Foronda, P., Valladares, B., Lorenzo-Morales, J., Ribas, A., Feliu, C., Casanova, J.C. (2003b): Helminths of the wild rabbit (Oryctolagus cuniculus) in Macaronesia. J. Parasitol., 89(5): 952 - 957. DOI: 10.1645/GE-3048

Foronda, P., Figueruelo, E., Ortega, A., Abreu, N., CASANOVA, J. C. (2005): Parasites (viruses, coccidia and helminths) of the wild rabbit (Oryctolagus cuniculus) introduced to Canary Islands from Iberian Peninsula. Acta Parasitolog., 50(1): $80-84$

Hardy, C., Callou, C., Vigne, J. D., Casane, D., Dennebouy, N., Mounolou, J. C., Monnerot, M. (1995): Rabbit mitochondrial DNA diversity from prehistoric to modern times. J. Mol. Evol., 40(3): 227 - 237. DOI: $10.1007 / \mathrm{BF} 00163228$

Hugot, J. P., Bain, O., Cassone, J. (1983): Sur le genere Passalurus (Oxyuridae: Nematoda) parasite de Leporidés. Syst. Parasitol., 5(4): 305 - 316. DOI: 10.1007/BF00009164 Juan, C., Emerson, B. C., Oromí, P., Hewitt, G. M. (2000): Colonization and diversification: Towards a phylogeographic synthesis for the Canary Islands. Tree, 15(3): $104-109$

Magnanou, E., Morand, S. (2006): Insularity and micromammal-macroparasite relationships. In: MORAND, S., Krasnov, B. R., Poulin, R. (Eds) Micromammal and Macroparasites. From evolutionary Ecology to Management. Tokyo, Japan: Springer-Verlag, pp 295 - 315

MAS-COMA S., FeliU C. (1984): Helminth fauna from small mammals (insectivores and rodents) on the Pityusic Islands. In: Kuhbier, H., Alcover, J. A., D’Arellano TUR, G. C. (Eds) Biogeography and Ecology of the Pityusic Islands. Monographiae Biologicae. Volume 52. The Hague, Netherlands: Dr. W. Junk Publishers, pp. 469 - 525 Mas-Coma, S., Esteban, J. G., Fentes, M. V., Bargues, M. D., Valero, M. A., Gala-Puchadesm, M. T. (2000): Helminth parasites of small mammals (insectivores and rodents) on the Pityusic Island of Eivissa (Balearic Archipelago). Res. Rev. Parasitol., 60(1 - 2): $41-49$ Mowat, V., Turton, J., Stewart, J., Lui, K. C., Pilling, A. M. (2009): Histopathological features of Capillaria hepatica infection in laboratory rabbits. Toxicol. Pathol., 37(5): 661 - 666. DOI: 10.1177/0192623309339501

Nogales, M., Rodriguez-Luengo, J. L., Marrero, P. (2006): Ecological effects and distribution of invasive nonnative mammals on the Canary Islands. Mammal Rev., 36(1): 49 - 65. DOI: 10.1111/j.1365-2907.2006.00077

SANCHEZ, S. (2013): Contribución al conocimiento de la parasitofauna (Helmintos y Artrópodos) de Mamíferos no Lagomorfos de Canarias. PhD thesis, Spain, Barcelona: University of Barcelona

Skryabin, K. I., Shikhobalova, N. P. (1950): A revision of classification of the family Heteroxynematidae Skryabin \& Shikhobalova, 1948. Dokl. Akad. Nauk SSSR, 71(3): 589 $-591$

Skryabin, K. I., Shikhobalova, N. P., Schulz, R. S. (1954): Trichostrongylids of animals and man. In: SKRYABIN, K. I. (Ed) Essentials of nematodology. Volume 3. Jerusalem, Israel: Israel Program for Scientific Translations, $704 \mathrm{pp}$. 
Skryabin, K. I., Shikhobalova, N. P., Orlov, I. V. (1970): Trichocephalidae and Capillariidae of animals and man and the diseases caused by them. In: SKRYABIN, K. I. (Ed) Essentials of nematodology. Volume 6. Jerusalem, Israel: Israel Program for Scientific Translations, $599 \mathrm{pp}$.

TenOra, F., Murai, E. (1978): Anoplocephalidae (Cestoda) parasites of Leporidae and Sciuridae in Europe. Acta Zool. Acad. Sci. Hung., 3-4: 415 - 429

Tenora, F., KoubKovÁ, B., Feliu, C. (2002): Redescription of Andrya cuniculi (Blanchard, 1891) (Cestoda: Ano- plocephalidae), a parasite of Oryctolagus cuniculus (Lagomorpha) in Spain. Folia Parasitol., 49(1): 50 - 54

VERSTER, A. (1969): A taxonomic revision of the genus Taenia Linnaeus, 1758 s. str. Onderstepoort J. Vet. Res., 36(1): $3-58$

Villafuerte, R., Calvete, C., Blanco, J. C., Lucientes J. (1995): Incidence of viral hemorrhagic disease in wild rabbit populations in Spain. Mammalia, 59(4): 651 - 659 . DOI: $10.1515 /$ mamm.1995.59.4.651 